\title{
REFLECTIONS ON THE INDO-EUROPEAN MEDIUM II *
}

The active diathesis may, if I am not mistaken, be defined as the category which 'originally' or 'essentially' signified that the subject performs a process. Often such a process exceeds the 'sphere' of the subject. The goal of the process may be expressed; it may also be indefinite and be omitted or completely absent: transitive, absolute and intransitive use or construction of the verbal form. Thus the Greek

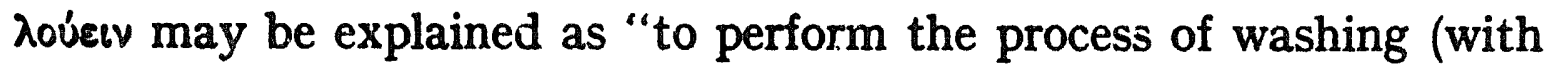

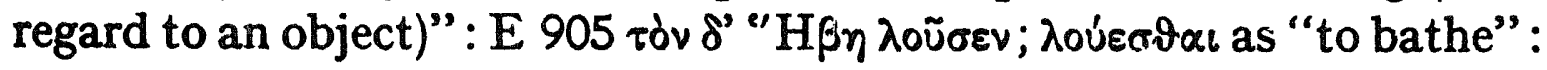

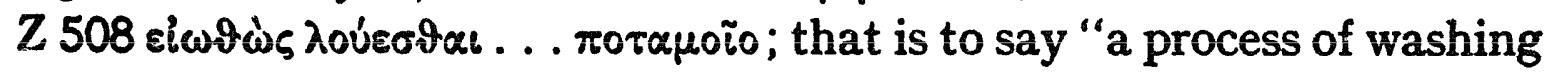
the body is taking place with regard to the person under consideration". As however bathing does not, as a rule, take place spontaneously or

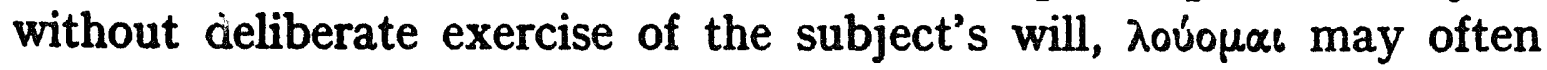
come to "I wash myself, I bathe", although bathing often was no more than going or plunging into a river, placing oneself under falling or streaming water, so that the process of "bathing" or "washing" requires no effort whatever on the part of the person who is in the water. A similar relation exists between well-known pairs such as $6 \lambda \lambda u \mu \iota^{\prime}$

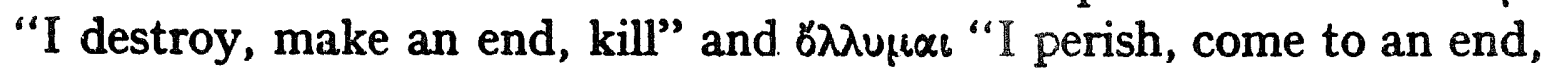

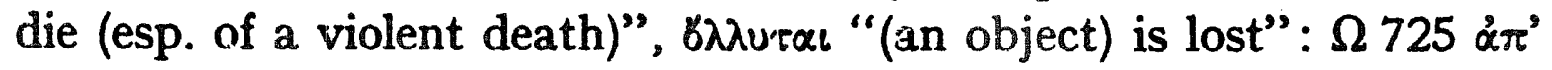

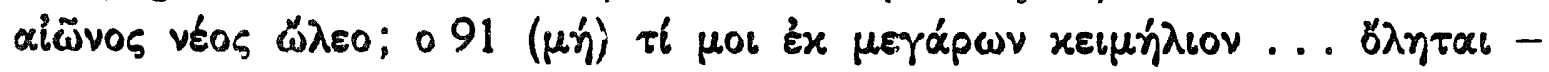

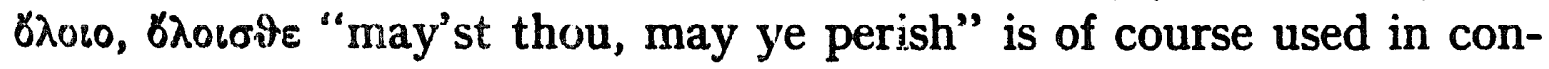
nection with involuntary happenings racher than the performance of processes originating with the subject -; $\pi \alpha \dot{v} \omega$ "I bring to an end,

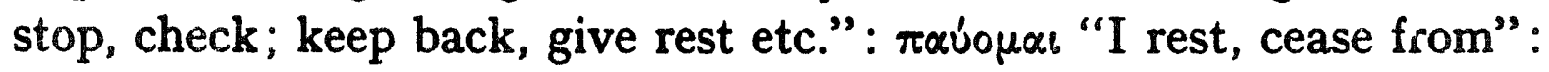

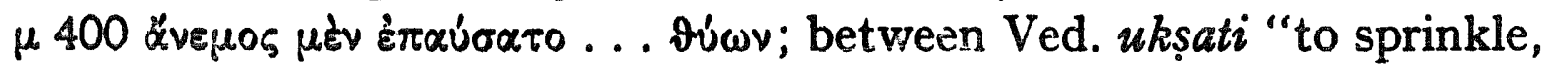
wet, moisten": ukșate "to drip, trickle"; kșanoti "to hurt, injure": $k$ șamute "to be injured (sich verletzen, wund werden)". If of the same verbal stem both voices regularly occu.red, we can easily imagine

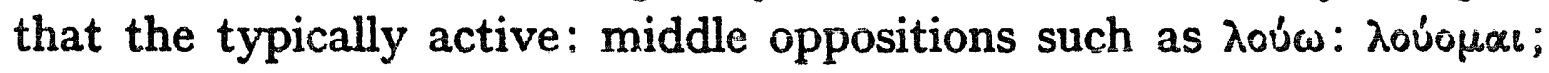
Lat. ornare: ornari; Skt. yajati: yajate became more and more pronounced ${ }^{144}$ ): whereas, for instance, in Sanskrit yajati is as a rule

-) for part I see volume IX, no 1 page 30.

144) For Vedic instances see Delbrück, Altindische Syntax, p. ¿36 if. 
used with reference to the officiating priest and yajate when referring to the institutor of the sacrifice or to one who makes an offering on his own account, there are many exceptions and yajati is (e.g. RV. 1, $27,13 ; 3,32,7)$ not rarely used where the idea of worshipping on one's own account is by no means excluded.

The so-called reciproque middle admits of the same explication. The Greek $\mu \alpha \chi_{6} \mu_{\varepsilon} \vartheta \alpha$ may 'originally' have meant no more than: "fighting taikes place with regard to us, in our sphere, with us". As

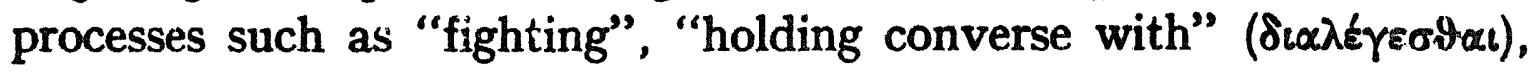

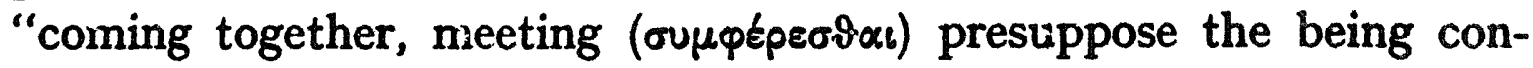
cerned of two parties, and as it is out of the question that these parties, or one of them, fight another person or group of persons, or that others are performing the process, $\mu \alpha \chi^{6} \mu_{\varepsilon \varepsilon}{ }^{\alpha} \alpha$ must mean "we fight". Similarly, in Sanskrit, samvadate "to speak together"; spardhate "to emulate, to complete"; cf. also SB. 2, 4, 3, 4äjim ajämahai (with an acc.) "let us run a running-match (race)".

That such verbs as $\gamma^{\prime}(\gamma v e \sigma \vartheta \alpha \iota$, Lat. nasci "to be born", Skt. mriyate, Lat. morior "to die" etc. are media tantum is clear. The idea expressed by Skt. sacate, Gr. Eँropal, Lat. sequor must have been "the process of going with or being together shows itself with regard to him, me": compare the etymologically related Skt. saca "near, at hand, along, together (with), in, at, betore, by, in the presence of", saci "together, along with"; Lat. secus "by, beside, along, on; following, later etc."; sequior "inferior". Nearest to the above definition are places such as RV. 2, 1, 3 tvam vidhartah sacase puramdinya "du, O Austeiler, bist der Puramdhi gesellt" (Geldner); 1, 125, 1 rāyas poṣena sacate suvīrah "... with regard to him who has many sons the idea of being with increasing wealth becomes actual", i.e. "reich an Söhnen wird er wachsenden Besitzes teilhäfti sacate sadä "er steht jederzeit in dem Alter, in dem man die Vollkraft besitzt"; 4, 5, 14 anäyudinäsa äsatã sacantām "it must happen to them to be together with ...", i.e. "without weapons they must lapse into Non-being". In these cases the verb is accompanied by the instrumental, which however is not necessary: AV. 6, 42, 1 sakhäyãv iva sacãvahai "we two will (must) hold together like friends". Of one from whose body a spear is drawn Homer says, M $395 \delta \delta \dot{\varepsilon} \sigma \pi \delta \mu \varepsilon v \circ \varsigma \pi \dot{\varepsilon} \sigma \varepsilon \delta$ doupl, where the verb is used of the will-less following of the motions of another thing

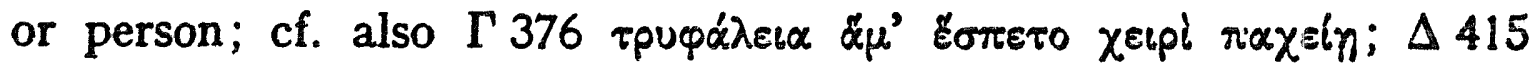




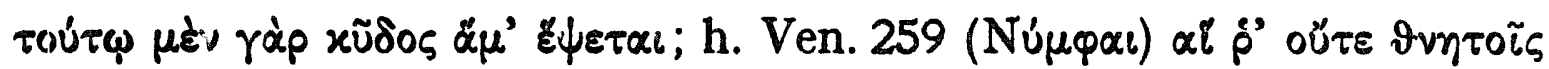

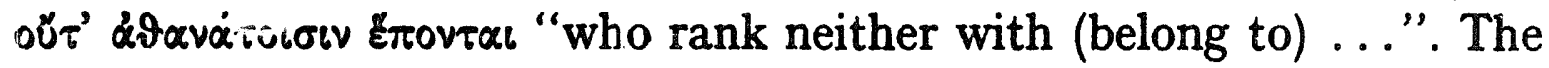
Latin sequor "se dit d'un objet qui prend facilement la direction qu'on lui donne, qui vient facilement" ${ }^{145}$ ): Varro R.R. 1, 47 celerius rumpuntur quam secuntur "they resist more strongly than they yield".

A clear instance of a typically medial verb is xeĩual: Skt. sete, the Greek verb occurring in meanings such as "to lie, to lie outstretched, to repose, to lie sick or wounded, dead, unburied; (of places) to be situated; (of goods) to lie in store; (of laws) to be laid down, to be established" etc., the Sanskrit "to lie, to sleep". "To be seated" ("̈ $\left.\mu_{\alpha \iota}, \bar{a} s t e\right)$,

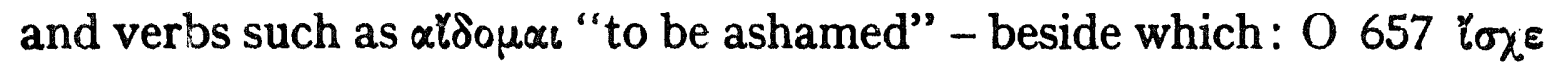

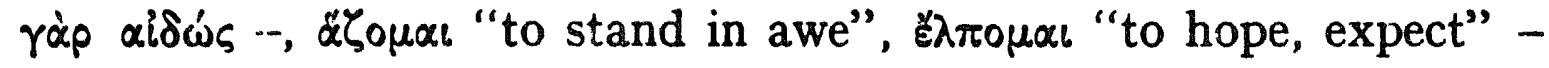

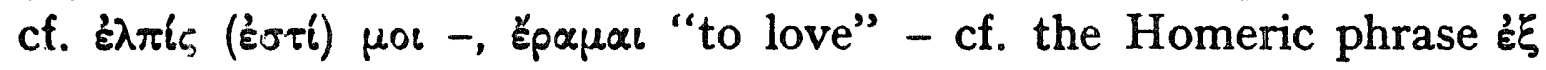

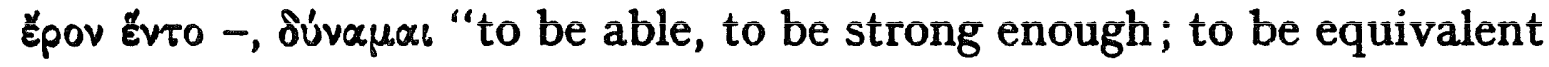
to, to be equal, signify etc." are likewise perfectly intelligible.

The occurrence of active forms "à côté du medio-passif avec une valeur analogue" 146) (e.g. Lat. Plaut. Pe. 453 male res vortunt quas agit "his undertakings turn out poorly"; Ter. Eun. 912 move vero ocius) does not form an objection to the above explanation, because the process expressed by the active not necessarily concerns any explicit or implied external object ${ }^{147}$ ). Compare e.g. in Vedic kși(kșeti, kșiyati) with the acc. "to inhabit (a place)"; without an acc. "to stay, abide, reside, remain, be quiet"; dunoti "to burn" (with acc.): "to be consumed with sorrow etc." (without an acc.); dham"to blow (a conch-shell) etc.: to blow (as wind)", etc. This phenomenon and the indifference with regard to diathesis of participles (Lat. sequens) or other nominal formis and imperatives ( $\pi \alpha \tilde{u} \varepsilon)$ may not be confused. These forms were no cloubt, in prehistoric times, less intimately connected with the personal verb forms which had developed the diathetic opposition than in the historical period. I would hesitate to consider, with Schwyzer-Debrunner ${ }^{148}$ ), the type $\pi \alpha$ ṽ an argument

145) A. Ernout et A. Meillet, Dictionnaire étymologique de la la:ıgue latine3, Paris 1951, p. 1087.

146) Ernout-Thomas, Syntaxe latine 2 , p. 203.

147) Incidentally a middle form may (if appearances are not deceptive!) have arisen afterwards to express one of the meanings which are usually expressed by a middle: lavari instead of lavare "se laver" (example adduced by Ernout-Thomas, o.c.2, p. 203).

148) Schwyzer-Debrunner, o.c. ${ }^{2}$, II, p. 224. 
in favour of the theory of a general absence of diathetic opposition in early Indo-European ${ }^{149}$ ).

The order in which the 'meanings' of a verb are enumerated in the dictionaries is not always such as to bring out the characteristics of its diathesis. Thus, $\mu \varepsilon \mu \varphi о \mu \alpha \iota$ means, according to Liddell and Scott, "to blame, censure", 1. c. acc. pers. (Hes. etc.); 2. c. dat. pers. et acc. rei (Sappho etc.); 3. c. dat. pers. only "to be dissatisfied with, find fault with"; 4. c. gen. rei only "complain of"; 5. c. inf. with $\mu$ 'ं; 6. abs. "Sind fault, complain". Now the verb probably expressed a feeling of dissatisfaction, discontent, resentment, which is more satisfactorily indicated by the translation of the 'non-transitive' functions 3 etc. than in 1 and 2 where the English language prefers short translations by means of verbs which are used transitively.

Not infrequently the etymology of a verb helps us to solve such at

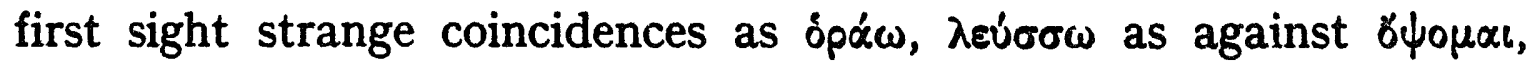

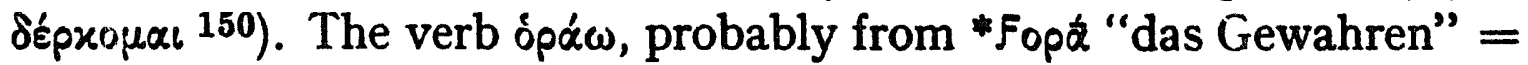
OHG. wara "attentiveness", belongs to OHG. wart "watchman, keeper etc." (cf. Gr. oũpos "watcher, guardian"; ఫupawpbs "doorkeeper") and other words expressing modifications of the idea of "paying attention to, looking at ... (wilfully); to watch" - cf. also

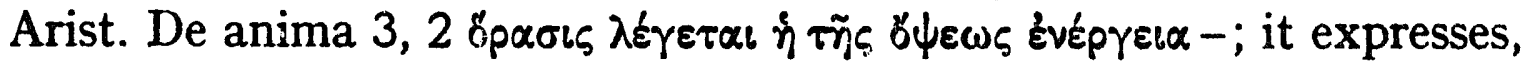
in Greek, also such ideas as "to give or take heed", and the construc-

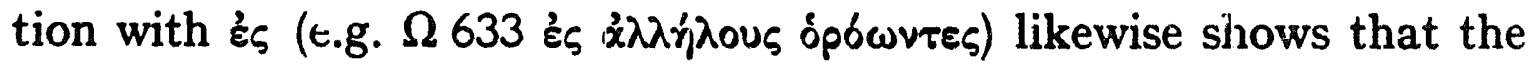
subject must 'originally' have been understood as performing the process. The cognate Latin verb vereor is a good example to show that a root is in principle by itself not characterized by a definite diathesis. Meaning "to feel awe of", "éprouver une crainte religieuse ou respectueuse pour" 151) rather than "ängstlich beobachten" 152) it signified that a person was affected by (a special sort of) attentiveness. ${ }^{153}$ ) The

149) See also Wackernagel, Vorlesungen über Syntax, I², Basel 1926, p. 122.

150) For these verbs see J. Vendryes, Sur les verbes qui expriment l'idée de "voir", Comptes rendus Acad. des Inscr. et Belles Lettres, Paris 1932, 192 ff. and A. Prévot, Verbes grecs relatifs à la vision et noms d'oeil, Revue de Philologie, 61, Paris 1935, p. $133 \mathrm{ff}$; $233 \mathrm{ff}$.

151) A. Ernout et A. Meillet, Dict. étym. de la langue latine $3,1278$.

152) J. B. Hofmann, Lat. etym. Wtb.3, II, Heidelberg 1954, p. 757.

153) Attention may also be drawn to $2 \pi l$... öpopat (Odyssea) which while being related to the active spów, expressed the idea of "keeping watch". The underlying function of the middle endings may have been to signify that a 


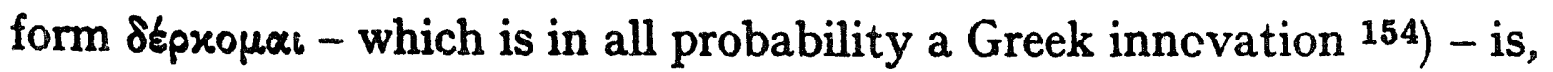
however, related to Skt. drști- "sight, faculty of seeing, view" (cf.

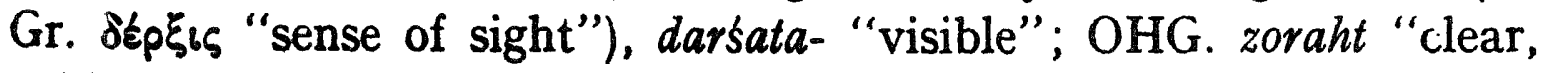

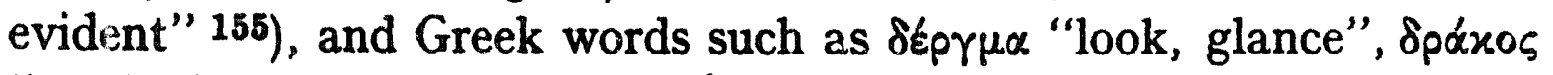
"eye": the sense of the root derk- must have been "(to be able) to see, to look, to glance, to be visible": the sense of the Greek verb was rather strong. which is also apparent in expressions such as detvóv,

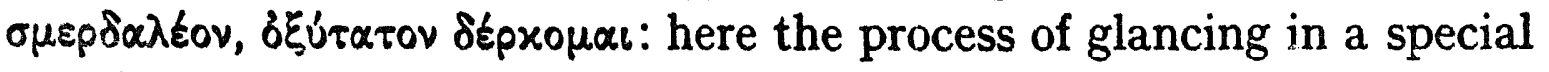
way is not viewed as an external process performed by, but as one acting upon a person, as producing a certain result on him: "to look terrible etc.". The sense of "being alive" (e.g. A 88) is likewise in harmony with the function of this diathesis. The use of derivatives of the root leuk- which has furnished various words for "light" (Lat. lux, Ved. roka, Arm. lois etc.; cf. Gr. גeuxós "white" 156)) in the sense of seeing may be explained from those ancient views of this process according to which the eye was a sort of lantern from which rays of light leap forth ${ }^{157}$ ). Seeing being considered some active shining or giving light, the active verb $\lambda \varepsilon \dot{v} \sigma \sigma \omega<{ }^{*} \lambda \varepsilon \dot{u} x-j \omega$ was a very adequate expression: "le sens de $\lambda \varepsilon v \dot{c}(\sigma \omega$ est un sens 'actif" "158); it often means "to look at, gaze upon". As however seeing also presupposes the reciption of light impressions, middle forms were no anomaly: they are indeed mentioned in the Dhātupātha $(4,2$ lcbate $; 6,3$ locate $)$.

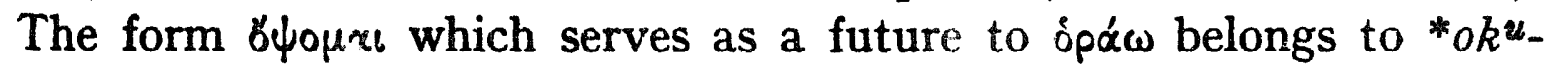

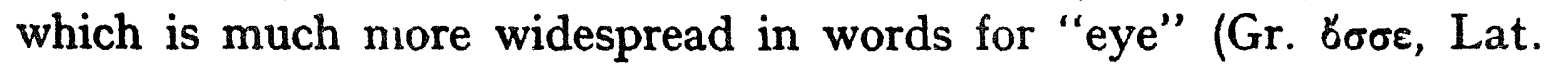
oculus etc.): there can be hardly any doubt that it originally conveyed the sense of "something wishes to come to, to reach a person's

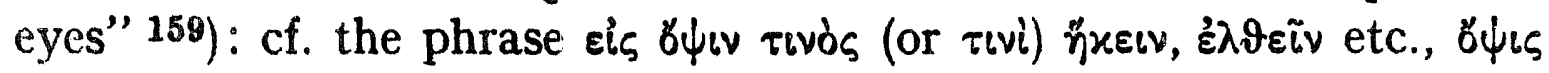
expressing the idea of "power of sight, vision, sense or organs of sight"

special 'power' or, to use a somewhat more 'mudern' terminology, rather a quality, virtue or activity made its presence felt in the subject.

154) I refer to $\mathrm{Hj}$ Frisk, Griech. Etym. Wtb., Heidelberg 1954-, p. 368.

155) For other cognate words see A. Walde-J. Pokorny, Vergl. Wtb. der idg. Spr. I, Berlin-Leipzig 1930, $806 \mathrm{f}$.

156) Walde-Pokorny, o.c., II, $408 \mathrm{ff}$.

157) For these ideas in ancient Greece see W. J. Verdenius, Fimpedocles' doctrine of sight, Studia Vollgraff, Amsterdam 1948, p. $155 \mathrm{ff}$.

158) Prévot, o.c., p. 247.

1s9) Not: "désirer appliquer l'organe de vue à" (cf. Prévot, o.c., p. 148 f.; this author does not consider the problem of thr genera verbi). 
as well as "aspect, thing seen, sight". The present $\sigma_{\sigma \sigma o \mu a b}\left(<^{*} o k^{*}-j o-\right)$, though as a rule meaning "seeing with the mind's eye" and hence "having a foreboding of, etc." admits of the same explication. Similarly the related Anc. Indian ikșate which combines the meanings "to see" and "to have a thought, auf einen Gedanken kommen"; like that denoted by бorouar this was quite intelligibly expressed by the middle voice.

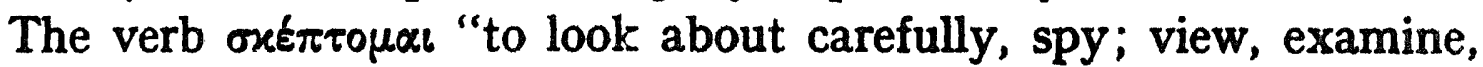
consider; think of beforehand, provide" is - in contradistinction to the cognate oxorkw "to behold, conte plate; to look to or into, to consider, examine etc." which supplies part of its tenses - a medium tantum ${ }^{160}$ ), a fact which is not easy to explain, the less because the related Skt. pasyati, Lat. specio, are mostly or regularly active. It may perhaps be suggested to explain the meanings "se préoccuper de (sens de caractère moral)" and "chercher à savoir (sens de caractère intellectuel)" from the medial nuance of the idea expressed by the root and to consider the sense "to look about carefully" as a case of a 'dynamic' or 'intensive' middle 161).

In contradistinction to $\varepsilon \dot{\varepsilon} \lambda \lambda_{\omega}$ "to be willing (of consent rather than desire, to wish)" - عُย่ $\lambda \omega$ often supposes "un a.tto energico di volon-

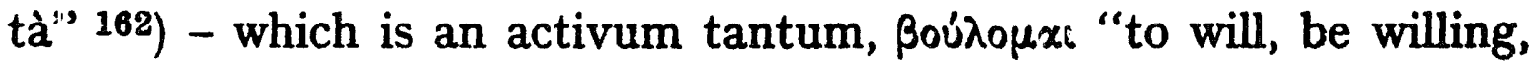
wish (usually implying choice or preference ${ }^{163}$ ))" is practically speaking always a medium. The former verb possibly belongs to OChS. želéjg "to wish, desire" 164), the latter derives from the same root and has been explained as "sich (im Geiste) auf etwas werfen" 165). Anyhow the difference in diathesis seems to be intelligible.

Viewed in the above light the middle diathesis is no redundancy. 'Semi-primitive' 1611) and archaic man evidently felt a want to avoid,

160) For a discussion of the meanings see also Prévot, o.c., p. $239 \mathrm{ff}$.

161) Compare R. Kühner-B. Gerth, Ausführliche Grammatik der griechischen Sprache, Satzlehre I4, Leverkisen 1955, p. 101 : "Verben, welche in der Medialform eine innere, geistige Thätigkeitsäusserung ausdrücken".

182) Alfonsina Braun, Nota sui verbi greci del 'volere', Atti del $\mathbf{R}$. Istituto Veneto di scienze, lettere ed arti, 98 (1938-9), p. 337 ff., esp. p. 341.

103) Liddell and Scott, Greek-Engl. Lexicon, New Edition, s.s.v.v.

164) Frisk, o.c., p. 447 f.

105) Cf. P. Kretschmer, Glotta 3, p. 160 ff.; Frisk, 0.c., p. 259.

166) In order to avoid misunderstanding I repeat what I have written ilready several times in other publications: I use the terms 'primitive", "prescientific' etc., exclusively in the scientific and technical sense given to it for 
for a variety of reasons, an active form, or preferred to use a more or less 'eventive' expression. Instead of attributing the performance of a process to a subject which in many cases was not or only vaguely known to him, he made the person (or object) which was the 'seat' of the process the subject, connecting it with a middle verb. There is indeed no denying that it is - even for us - in many cases a more easy and obvious procedure to assert something of the person who (or thing which) undergoes a process and who is as a rule well known, than to the power, being, entity or phenomenon which scientifically or objectively speaking is the author or originator of the process. So far the factors conditioning the rise and spread of this category are related to those which lead, in many languages, speakers to use 'eventive expressions' or 'einen Nominalbegriff, der nicht grammatischer Subjekt 167) im Satz, aber psychologisch Mittelpunkt der Aussage ist, in den Nominativ umzusetzen" ${ }^{168}$ ). Thirty years ago Havers ${ }^{169}$ ) already drew attention to the fact that beside forms such as the active Germ. ich denke an expression for "die unwillkürlich in unserem Innern auftauchenden Gedankenassoziationen" is far from rare. "Im Französischen gebraucht man avoir + Subst., um das Nichtgewollte und Unbeabsichtigte eines Vorgangs zu bezeichnen, also im Gegensatz zu elle cria ein elle eut un cri". In Polish the construction mnie sie chce "es will sich mir" occurs beside ja che: "ich will".

instance by G. van der Leeuw (see e.g. L'homme primitif et la religion, Paris 1940), who did not tire of arguing that 'primitiveness' - as contrasted with 'modernity' - is not, or not primarily, a chronological distinction, but a difference in 'anthropological structure'; although elements of 'primitiveness' may predominate in archaic men, in children, in poets, in the 'uneducated' of all times and countries, civilized and educated Western people are by no means free from it.

168) The onus of this formulation should be left on the author.

108) K. Brugmann, Der Ursprung des Scheinsubjøktes, Ber. Kon. Sächs. Ges. d. Wiss. 69 (1917), p. 27; the same, Grundrisz d. vergl. Gramm. d. idg. Spr. II, 3, p. 923 f. Cf. also E. Lerch, Prädikative Participia, 1912, p. 89 (cette colonie est difficile d administrer instead of il est difficile d'administrer cette colonie; A. F. Salonius, Vitae Patrum, Lund 1920, p. 258 (on the greater ease of 'personal' constructions); F. Strohmeyer, Der Stil der französischen Sprache, Berlin 1924, p. 167 on the use of Fr. je suis obei, Lat. invideor, Gr. థiovoũ $\mu \alpha$.

169) Havers, in Wörter und Sachen 12, p. 166, who quotes H. Steinthal (Zs. f. Völkerpsych. und Sprachw. 1 (1860), p. 87): "Im Gfiühl ist der Mensch zu passiv, als dasz er sich in ihm als tätiges Subjekt bezeichnen könnte". 
Although they have no direct bearing on our subject, the observations made, in the year 1921, by Meringer 170) on the "Innere Sprache in der Erregung" may also contribute some data to deepening our insight into the 'mentality' or state of mind which led to the frequent use of verbs in the middle diathesis. "Dasz der eigene Gedanke als etwas Fremdes erscheint, findet sich auch bei naiven Menschen bei völliger Gemüisruhe. Bei Lessing, Minna von Barnhelm II, 1 sagt das Fräulein: Siehsi Du, Franziska; da hast Du eine sehr gute Anmerkung gemacht. Worauf Franziska: Gemacht? Macht man denn das, was einem so einfallt?" The same scholar shed, by a large number of linguistic and literary examples, light on the phenomenon "der inneren Sprache", which is often misinterpreted by the thinking and speaking subject: although it arises in the 'psyche' of the speaker, it is not regarded as proceeding from his own initiative; in his view $h$ is thoughts, ideas, desires etc. are of 'objective' or 'external' origir ; they are anyhow not producis of his own making.

It is a great asset to the explication of the 'original' function of the middle voice defended in this article that verbal forms expressing that something is happening with regard to the subject, that it is affected or reached by a process, that a person or a thing is touched, struck, moved by an event, comes across, or falls in with, an occurrence etc., that the subject is involuntarily, accidentally or voluntarily concerned in a process or attains to a condition etc., the 'agens' being unknown or passed over in silence, are widespread in many languages. Thus the Malay terr-tidur means "fallen asleep, (the subject) falls asleep", tër-sènyum "smiling, to smile" 171); tiada tĕr-arikat "(it) cannot be lifted up"; saya tiada těr-jalan "I am not able to walk": tër-kĕpun "(to be) surrounded"; těr-kějut "(he, she, I etc.) startled"; here also these derivatives sometimes impress us as 'transitive verbs': i kan racun "to get down poison", Toba Batak tar-dege bisa $^{2} a h u^{3}$ "I ${ }^{3}$ have by accident trod ${ }^{1}$ on a venomous caterpillar"." Comparable categories occur in the Papuan idiom of New Guinea. According to Father Drabbe ${ }^{172}$ ) the grammatical subject alway: is a 3rd pers. singular, so that a form translated by "I shall die" literally means: "it will make me die" or something to that effect; a form for "I get

170) R. Meringer, in Wörter und Sachen, 7 (1921), f. 50; cf. p. 52; p. 62.

171) See the present author's observations in Lingua, 3 (1952), p. $22 \mathrm{ff}$.

i72) P. Drabbe, Spraakkunst van het Marind, Wien-Mödling 1955, p. 100. 
hungry": "hunger begins to torment me". In this way the Marind express a variety of processes, e.g. "to be jammed, oppressed, swell up, fall ill, be satisfied". One could also recall such distinctions as, mutatis mutandis, exist in Caucasian languages between the action type "I write" and the sensation-type: "me-sound-is" 173).

One could raise the question as to why there are so many active verbs denoting ideas which might, on a superficial view, be expected to belong to the middle diathesis, e.g. "to be hungry": Gr. $\pi \varepsilon$ rvów.

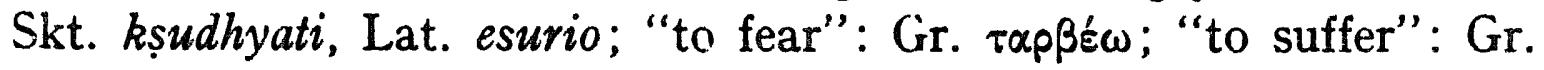
à $\lambda \hat{\varepsilon} \omega$; "to blow (of the wind)": Skt. väti; and also as to why the impersonal verbs are almost exclusively active in form, although especially the so-called impersonalia of sentiment (including thoughts etc. which loom upon the mind) ${ }^{174}$ ) convey processes which may be said to befall a person: Lat. (me) miseret "I feel pity or compassion"; (me) paenitet "I repent, I ar.1 sorry" 175). I am under the impression that both phenomena are closely connected.

173) A. Dirr, Einführung in das Studium der kaukasischen Sprachen, Leipzig 1928, p. 63.

174) The distinction often made between three groups of impersonalia (those referring to natural, especially meteorological phenomeina: Lat. pluit, Gr. Bpovtã ; the so-called impersonalia of sentiment, and those expressing possibility, propriety, recessity etc.: Lat. mi.hi licet, placet, me iuvat, necesse est, oportet etc. is, especially with regard to the first and second group, rather artificial. Many impersonalia of the third class are young and due to analogical processes.

175) In Sanskrit impersonalia in the proper sense of the term (subjectless finite verb form) are rare; cf. e.g. Mbh. 1, 47, 26 na cāpy avamatasyeha vāso roceta kasyacit; RV. 2, 30, 7 na mä taman na śraman nota tandrat "let it not exhaust me, let it not tire me, let it not make me languid": Monier Williams (M. Monier Williams, Skt.-Engl. Dict., p. 438; 1096) translates the first phrase by "may I not be exhausted" (the verb tam- (IV 'âmyati) meaning "to gasp for breath, faint, be exhausted", tamayati (caus.) "t " suffocate"), the second by "may I not become weary" (\$̌ämyati"to becorne wcary", whereas Sâyana considered the god Indra, to whom the text is addressed, to be the subject: sa indro mām na tamat na tamayatu na glapayaiu etc. It seems inevitable to disagree with Delbriick (Delbrück, Vergl. Syntax, III, p. 30), who, taking the line that 'the intransi ive meaning' of these verbs was original, argued that in the beginning the sentence was not impersonal, but assumed that character and outward form in order to express more unequivocably that the subject did not act, but was submitted to and overwhelmed by a stronger power. So it became the object of the sentence and the verb became impersonal, the 'agent' being beyond the limits of the speaker's intelligence. This argument seems 
As is well known a considerable many of terms belonging to the ancient vocabulary of the I.-E. peoples and a variety of phrases and constructions may be explained from their belief in power or powersubstances. That is to say: they may be considered to have originated in a mentality and view of life which assumed the existence of a great number of more or less autonomous potencies or power-substances which within some form of experience were supposed to be present in objects, persons and phenomena and by virtue of which these are

needlessly intricate. As on the one hand these verbs may, in principle, be construed transitively and intransitively, the intransitive use of asramat AV. 6 , 60,2 "has toiled" is no certain evidence of an original intransitive character of the verb: cf. e.g. also 2, 24, 9 süryas tapati, but 10,27, 23 tapanti prthivim. A similar argument with regaid to RV. 10, 34, 11 striyam drștvāya kitavam tatäpa has likewise failed to convince me. It is true that as a rule the subject of the absolutive is the so-called psychological subject, or rather the agens, of the chief process of the sentence. This does however not imply that it should always refer to a noun in the nominative (in an active sentence) or to an instrumental (with a passive verb). In addition to the examples of at first sight free constructions with the absolutive collectied by other authors (see e.g. J. S. Speyer, Sanskrit Syntax, Leiden 1886, p. 2.'77; the same, Vedische und Sanskrit-Syntax, Strassburg 1896, p. 68; L. Reno d. Grammaire sanscrite, Paris 1930, p. 128) some instances may be quoted in irder to show that nothing prevents its refe.ring to nouns in other cases or e rer to subjects which are only tacitly understood: Jaim. Br. 2, 64 tad adbhir abhyukșya chāyāyām nișektavai brüyāt "so soli er befehlen (den Rest), nachdem dieser mit Wasser besprengt worden ist, .. auszugiessen" (Caland); Mān. G.S. 2, 11, 5 gavta m khātvā yat taih pā musubhị̆ pratipüryeta tad $2 \bar{\pi}$ "(a spot) where a pit, which has been dug, can be filled up (again) with the same earth" (cf. Ásv. G.S. 2, 8, 2); Āp. Dh. S. 2, 11, 29, 7 punyāhne ... ubhayatah samākhyāpya sarvānumate mukhyah satyam praśnam brisyät "an eminent person shall answer the questions put to him according to truth on an auspicious day ... with the consent of all, after having been exhorted (viz. by the judge) to be fair to both sides"; Mbh. 1, 11, 10 tam drștvā sápamokşas te bhavita "you will be relieved of the clirse on seeing him"; 191, 13 teşām draupatim drștvā ... prādu. āsin manobhavah "when they looked at D. love manifested itself"; 12, 148, 8 visrjya dhanasarvasvam bhartā vai saranam striyāh "casting off all her possessions a woman skould consider her husbanc her (only) refuge"; Bāna, Kād. p. 36 (NSS. 7th ed.) ... ity abhidhāya gate ca tasmin (the subjects being identical! räjā ... aprcchat. Compare also instances such as Sv. Up. 1, 11 jnātvā deva $n$ sarvopāsāpahānih "by knowing God there is a falling off of all fetters". In later texts of a sometimes very free or incorrect style we encounter instances such as: Käl. Pur. 45, 101 f. (kälih) pratasthe ... tam utsrijya dvijam. atha sambhur nija m rüpam āsthāya himavatsutâm' ram samutsriya gacchantim anvayāt "Kāli having dismissed thai brahman 
rowerful, effective, influential ${ }^{176}$ ). Not rarely these terms denoting power substances are usec' as subjects of verbs expressing such ideas as seizing, laying hold of, coming over, falling upon, striking, overwhelming; entering into, irıspiring, animating etc. They are mostly conceived impersonally, but often also regarded as more or less personal in character, a distinction which - as has become apparent in the last decades - is unessential 177). Thus it reads AV. 6, 69, 3 man i varco atho yaśo atho yajñasya yat fayah, tat mayi prajäpatir ... armhatu 'in me be 'brilliance' and 'glory', also the fatness that belongs, to the sacrifice; let P. fix that in mo:"; 14, 2, 54 ff. tejo (bhago, yaśo etc.) goșu praviștam yat tenemām sam srjämasi "with the 'energy' ('fortune', 'glory') which has entered into the kine, we unite this woman".

In view of the more or less substantial and independent character of what in our eyes would be qualities the above places and those which are to follow are no matter for great surprise. Vedic man could for instance be united with what he had heard (AV. 1, 1, 4), it could be in him (AV. 1, 1, 2); all terrible things and deaths are in the cow of the brahman (AV. 12, 5, 13). The Homeric instances are well-known:

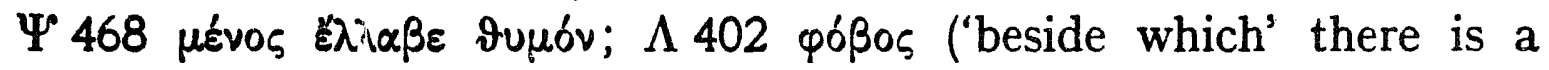

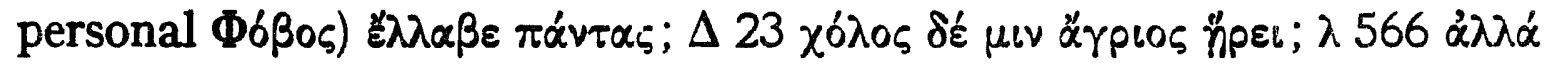

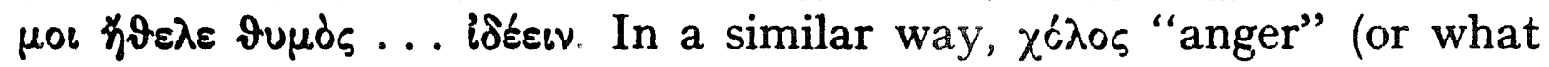
is felt as such) is spoken of as entering into or being in the breast

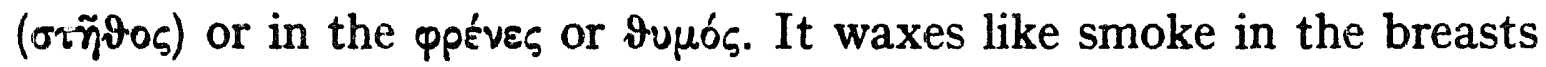

left; thereupon Sambhu (who had disguised himself as that brahman) after having re-assumed his own appearance followed the daughter of the Himavat who (= Kāli) went away after she had dismissed him"; 46, 16 drștvā yasyaivāgrabhägam sanetram trānāya syād darśanam süryatulyam "when one has seen his front side with his eyes, his appearance will conduce to help". The conclusion may therefore be that the translation "es peinigte den Spieler, als er das Eheweib ... anderer sah" (Geldner) of RV. 10, 34, 11 is correct; the words in the text need not be regarded with Delbrïck as having originated in s. d. kitavah tatäpa.

176) See e.g. W. Havers, Primitive Weltanschauung und Impersonalia, Wörter und Sachen 11 (1928), p. 75 ff.; H. Günther, Das Geistesleben der Naturvölker und indische Weltanschauung, Archiv für Völkerkunde, 2 (Wien 1947), p. $69 \mathrm{ff}$; R. B. Onians, The origins is European thought, Cambridge 1954, passim; Gcnda, Anc. Ind. ojas, Lat. "augos etc., Utrecht 1952, passim and esp. p. $46 \mathrm{ff}$.

177) See my "Gods" and "powers" in the Veda, Disputationes Rheno-Trajectinae, I, 's-Gravenhage 1957. 
of men ( $\Sigma 110 \mathrm{f}$.). Being subjected to the mastery of the emotions of the moment archaic man ascribed them to foreign powers. Not being able to understand his own conduct and behaviour he concluded that foreign powers had entered him or had taken possession of hirn. Thus terms such as ףvpós appear as grammatical subject and as independent entities to which the psychical activities were attributed. As to the ancient Germanic languages ${ }^{178}$ ) it may be regarded as certain that such words as Anc. Engl. egsa, gryre, broga which formerly were taken to denote the emotions of fear, terror etc. do not refer to the subjective sensation, but to the objective terrible, to "das Schrecknis, den Graus, schreckenerregende Erscheinungen". The Germanic word families represented by Germ. Geist, Wut, $M u$ ut were in all probability originally indicative of "seelische Bewegungen als etwas von auszen in den Menschen kommendes" 179), of external superhuman power. "Die inneren geistigen Prozesse (wurden) als etwas Fremdes, den Menschen Entgegentretendes, auf ihn Einstürmendes und von ihm Besitzergreifendes empfunden" 180): cf. such phrases as the German es beriihtt mich schonerzlich; Schmerz befällt ihn; Angst, Furcht ergreift ihn; Hasz zerfleischt mich; was sieht Dich an? which are still usual 181).

Other Vedic instances of these expressions are: the verb grabh- or grah- "to take, catch, seize, overpower" when said of gods, demons, diseases etc., e.g. R.V. 10, 161, l grähir jagräha yadi vaitad ena mas tasyä indrägni pra mumuktam enam "or if then 'seizing' or 'seizure' has seized him, do Ye free him from it, O Indra and Agni" (cf. also AV. $3,11,1)$. Though usually called a demon or disease - "Krankheitsdämon" (Geldner 182)) -, the expression does in my opinion hardly say more than the idea of 'seizing' viewed as a power substance. Cf. also AV. 2, 9, 1 (wherc an amulet is implored to free a man from possession by demons): muñcemam rakșaso glähyä adhi yainam jagräha

178) R. Meringer, in Wörter und Sachen 7, p. 50 ff.; L. L. Schüsking. Untersuchungen zur Bedeutungslehre der angelsaksischen Dichtersprache, Heidelberg 1915, p. 30 etc.; ‥ M. Meyer, Die Bedeutungsentwicklung von germ. "niōta- Thesis Leipzig 1926, p. 30; 41 ff.

179) Meringer, o.c., p. 64.

180) Meyer, o.c., p. 41.

181) Cf. also M. P. Nilsson, Archiv für Religionswissenschaft 22, p. 374 f.

182) K. F. Geldner, Der Rig-Veda übersetzt, III, Harvard 1951, p. 389; "fit": M. Bloomfield, The Atharva-veda and the Gopatha-brāhmaña, Strassburg 1899, p. 62. 
parvasu "release this man from the dernon, from the 'stizure' which has seized him in the joints", and 6,113,1 tato yadi tvä grähir annaśe "if from that 'seizure' has reached you". Another phrase of this type is e.g. RV. 5, 50, 3 dvișo yuyotu yuyuvih "the remover must remove the anemies". The word jinitar -"generator" occurs in the Rgveda only in connection with jajāna "has generated": $3,1,12$ ud usriyä janitä yo jajäna "he (Agni) who as a generator has begotten the cows". Though a nomen agentis and referring to an agens who is conceived personally this word may likewise be considered to have been a representative of generative power, its embodiment manifesting itself in a variety of single acts of creation.

Incidentally a nomen agentis in -tar-develops into a ame of frequent occurrence denoting a divine being especially concerned with the activity expressed by the root of the word, e.g. Dhätar- "the Founder or Establisher" 183). In this case also the above paronomastic phrase does not fail to turn up: AV. 7, 19, 1 dhätä dadhätu sumanasyamänah "let the Establisher, of favouring mind, establish"; 18, 3, 29 dhartā ha tvā dharuno dhärayätai "Dhartar (the Supporter), the supporting one shall support you"; thus a leader god, Netar, is (RV. 5, 50) invoked to lead his worshippers to prosperity. In these formulas the divine power is on the one hand stated and recognized, and on the other hand stimulated into a display of its characteristic capacity 184). From the point of view of Vedic religion they are perfectly intelligible: a power is stated or implored to give evidence of its specific activity ${ }^{185}$ ). They do not essentially differ from the phrase väto väti "the wind blows" - Văta also occurs as a 'god' - which is for instance found Sat. Br. 11, 5, 6, 9, the plural "let the winds blow" occurring AV. 4, 15, 8 vata $v \bar{a} a t u$. There is no reason whatever to regard the occurrence of the subject as tautological. Cíf. also TS. 7, 5, 20, 1 varștáa parjanyah paktā sasyam which probably meant: "Parjanya (must) prove himself

183) See e.g. A. A. Macdonell, Vedic Mythology, Strassburg 1997, p. 13; $116 \mathrm{ff}$; A. B. Keith, The Religion and Philosophy of the Veda and Upanishads, Harvard 1925, p. 206.

184) We also find neuter subjects such as SatBr. 1, 2, 1, 11 dhartram asidivam drmha "thou art a support, make the sky firm (hold the sky)".

185) Cf. e.g. also cases such as RV. 1, 32, 2 tvașíasmai vajram . . tatakșa "Tvaștar (the divine carpenter and architect) has constructed him his thunderbolt". 
to be the power controlling rain, the corn (must) prove itself to be a manifestation of the force of ripening" ${ }^{186}$ ).

Similar divine functionaries or "Sondergötter" were also known to other Indo-European perples ${ }^{187}$ ). With the Romans Potina taught a child to drink, Edissa to eat, Statanus to stand, Fabulinus to speak. The name of the 'goddess' $O p s$ is of course identical with the noun ops "resources", showing like Venus = AInd. vanas- n. "loveliness, desire", the personal as we!l as the power aspect of the divine. Ops is described as identical with the earth, who omnes opes humano generi ... tribuit 188). There was also an Ops opifera. The agricultural Lithuanians wurshipped, beside some higher gods, a very large number of Sondergötter: one of them assisted in sowing, another in ploughing, a third in threshing, another in milling or baking, etc. The universal German name of the thunder-god OHG. Donar, O.No. Thorr etc. is nothing else than the term for thunder ${ }^{189}$ ).

That the power occasioning an event or affecting the health, conduct, disposition etc. of a person is :often left unmentioned (cf. also

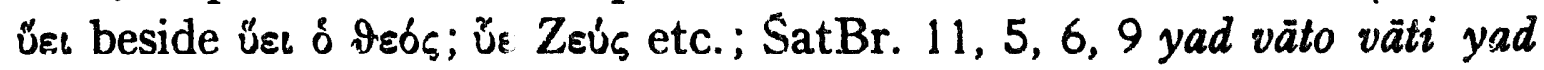
vidyotate yat stanayati "when the wind blows, when it lightens, when it thunders") may be ascribed to the tendency to express oneself 'euphemistically', to avoid mentioning the names of powers or powerful beings; to the phenomenon of ellipsis: it is often perfectly clear who is the author of the process; incertitude or ignorance of the name or character of the power or powerful being concerned in the process or, more generally, of the nature of the person or object producing an effect - the verbal act is ascribed to "einem nicht näher bezeichneten Etwas" 180 ) -, and to analogical processes. It is however clear

186) For this interpretation see the author's article on the periphrastic future in Sanskrit, Lingua 5, p. 158.

187) See e.g. E. Lehmann, in A. Bertholet und E. Lehmann, Lehrbuch der Religionsgeschichte I, Tübingen 1925, p. 69 f.; G. Wissowa, Religion und Kultus der Römer, München 1912, p. 37; F. Cornelius, Indogermanische Religionsgeschichte, München 1942, p. 114.

188) Paulus e Festo 203, 18.

189) F. Kluge-A. Götze, Etym. Nörterbuch der deutschen Sprache ${ }^{25}$, Berlin 1951, p. 142.

190) H. Corrodi, I las Subjekt der sog. unpersönlichen Verbe, Kuhn's Zs. 53 (1925), p. 1 ff.; p. 34. 
that in both cases the form of the verb is active, the explicit as well as the implicit subject performing a process.

There is on the other hand an unmistakable tendency in many languages to reduce, in the course of time, the number of impersonal verbs and to replace them by personal expressions. Whereas for instance Medieval Dutch possessed a great variety of impersonal verbs, the modern language, especially in its spoken form, has retained only part of them. Thus the subject was left unexpressed in sentences such as hem dorst (e.g. soe hi meer drinct, soe hem meer dorst), where nowadays the only common form is hij heeft dorst "he is thirsty", the personal hij dorst being used in the metaphorical sense (dorsten naar bloed, wraak, kennis etc.) and mij dorst occurring, occasionally, in archaising style. In a similar way our ancestors said: hem gruwet (hem gruwet altoos daer voren) where we use gruwen personally: gij gruwt van het kannibalenbloed (Potgieter); mi lanct na di as against the modern $i k$ verlang naar jou; hem gedachte sire vrouwen; mi wort bet: $i k$ word beter 191). Cf. also mine mesdade mi berouwen beside mi berouwet mire mesdade etc. $\left.{ }^{192}\right)$. The indefinite pronoun het, ' $t$ could, and in some cases still can, be added as a grammatical subject: het naect ten sceiden; het nauwet: nowadays het benauwt mij occurs beside bange dromen benaurven de zieke; alst ( $=$ als ' $t)$ hem misginc and the modern het gaat hem goed, slecht etc. Many impersonal verbs have fallen into complete disuse: mi bedinke: "I remember"; mi griset "I abhor"; mi miscomt "I am doing badly"; mi varet "I am afraid"; mi verdunket "it displeases me"; het pliet "it is a matter of habit" etc. In some cases the personal construction occurred, in Medieval Dutch, beside the impersonal use of the same verb: ic droomde beside mi droomde; ic grume iet 'I abhor something": mi gruret; often the personal construction survives: $i k$ droom, etc. Although there is up to the present a number of impersonal verbs in common use: het - bijt mij, het overkomt mij, het gaat mij slecht, het verbaast me, het past hem niet, other forms of the same type occur only in written language or more or less, formal style: het behaagt mij (e.g. hei heeft Hare Majesteit behaagd ...); het mishaagt mij, het verdriet mij, het berounot mij, such expressions as

191) These examples are borrowed from F. A. Stoett, Middelnederlandsche Spraakkunst, Syntaxis ${ }^{3}$, The Hague 1923, p. 6; $171 \mathrm{f}$.

192) Stoett, o.c., p. 170. 
ik vind prettig, ik heb er verdriet van, ik heb er berouw over being dt cidedly preferred in colloquial and even in standard usage.

Parallels may be adduced from German 193): in cases such as mich (later: mir) ahndet, ahnt: ich ahn(d)e the person who was affectied by the process was in the course of time shifted from the object to the subject position, for the impersonal construction was the older one. The early expressions for "I am hungry" and "I am thirsty" are likewise mich hungert and mich dürstet, the personal constructions are, however, used at an early date ${ }^{194}$ ). Originally the verb liisten was impersonal, accompanied by the acc. of the pers. and the gen. of the object: mich hat deines Dienstes nicht geliistet (Luther). There was a complication which facilitated the transition into the personal class: the gen. es which in the ancient language often accompanied an impersonal verb could be interpreted as the homonymous nom. ex. Thus Luther wrote: sie muszte nicht wieder zum Könige kommen, es liistete denn den König. After the example of es the nom. of other pronouns might occur also: tue, was dein Herz lïstet (Luther). The use of another pronominal or of a nominal subject is, in this case, infrequent, but Wieland wrote: das Ziel, wonach er liistet, Klinger: des Kapitains Fluch geliustet mich, and Herder: nach der verbotenen Speise liistet man am meisten. Another originaliy impersonal verb was the MHG. mich verdriuzet eines dinges, but nowadays the nominative of the subject has replaced the genitive. In accordance with its etymology ("to become too long") verlangen was in the early texts used impersonally: mich verlangt, compare also herzlich verlangt mich nach einer freundlichen Spur von Ihnen (Schiller) 195). In the modern language $i c h$ verlange nach $\mathrm{r}$ with $z u$ and inf. is the common construction, which is, in a definit sense, also transitive: er verlängt eine Erklärung. Special attention nuy be drawn to a personal use of meteorological verbs in a metaphorical sense ${ }^{196}$ ): beside es blitzt we find Augen und Waffen blitzen; beside es regnet: Geldstïcke regnen; Feuerküsse regnen auf den Marmor (Schiller) and even die Wolken regnen die Gerechtigkeit (Luther) and ein Baum, der Blüten rę̧net (Uhland). The

1.98) See e.g. O. Behaghel, Deutsche Syntax, II, Heidelberg 1924, p. 139.

194) Cí. also H. Paul, Deיıtsches Wörterbuch, s.v.

1.95) For other examples see Paul, o.c., s.v.

196) Cf. also F. Blatz, Neuhochdeutsche Grammatik, II, p. 259. 
possibility should a priori not be excluded that a personal verb arising beside an impersonal counterpart is a new derivative ${ }^{197}$ ).

A detailed exposition of the selevant facts would however be a superfluity as Havers has alread in the year 1931 198) summarized the results of some studies of thi phenomenon as far as the English language is concerned: "Das Alt- und Mittelengl. besasz noch eine Fülle von unpersönlichen Bildung nn. Bei Shakespeare lässit sich deutlich beobachten, wie die jüngere persönliche Konstruktion der älteren unpersönlichen Konkurrenz macht, was manchmal zu einer Vermengung beider Ausdrucksweisen führt. Heute steht, von vereinzelten Resten abgesehen, die persönlich Konstruktion auf der ganzen Linie als Sieger da". The conclusion drawn by this scholar, who follows in the footsteps of others ${ }^{199}$ ), is no doubt in the main right: this tendency to replace the so-called Empfindungsimpersonalia by personal verbs results from the inclination of the communities which spoke these languages to put the nominal or pronominal concept which was, psychologically, the centre of the enunciation in the nominative, casu quo to give it the position of the subject. The trend to apply this sentence structure also in those cases in which the former generation had preferred impersonal constructions must be due to factors of a cultural and psychological character, of a change in 'Weltanschauung' ${ }^{200}$ ) and of the penetration of more rational, ego-, or rather,

197) Cf. Behaghel, 1.c.

198) W. Havers, Handbuch der erklärenden Syntax, Heidelberg 19.31, p. 104 (with a succinct bibliography, see also p. 238).

${ }^{199}$ ) See e.g. Ph. Aronstein, Zs. f. franz. u. engl. Unterricht 22 (1923), p. 186 f.; M. Deutschbein, System der englischen Syntax2, Leipzig 1926, p. 109 ff. (with a bibliography).

200) We should however, in discussing the influence of archaic or 'pre-scientific' thought on language guard against the temptation unduly to isolate the phenomena relative to this insluence from comparable phenomena, in modern languages and thereby to over-estimate their peculiarity. We also have, in a great variety of cases, the option of a more 'personal' construction in which a personal subject performs the process and a logically synonymous construction in which external factors or attendant conditions are made the subject. Beside: he could not go out because it rained we may say: the rain prevented him from going out; beside the German: der arme Mensch geriet in die: furchtbarste Veraweiflung: da überfiel den armen Menschen eine furchtbare Verzweiflung; beside er fiel durch seinen Hochmut: der Hochmut veranlaszte seinen Fall, etc. See also $\mathrm{Ph}$. Aronstein, o.c., p. $174 \mathrm{ff}$. 
anthropocentric ideas, of more pronounced feelings of human selfconsciousness, of a more complete realization of man's own position in the world and of his power, influence and possibilities, of a decline of the archaic belief in gods, demons and impersonal powers affecting men and other beings with fear, panic, love, longing, sorrow, pain, regret, hunger, thirst, of an increasing inclination to ascribe the manifestation of these feelings and sensations to internal processes rather than external powers ${ }^{201}$ ).

Now, this process, the gradual disappearance of part of the impersonal verbs was, if appearances are not deceptive, at least in some provinces of the I.-E. territory in operation at an early date. Kühner and Gerth ${ }^{202}$ ) devote an entire paragraph to the discussion of the phenomenon that the Greek language often prefers, in connection with an infinitive as well as other forms, a personal construction to an impersonal. "Durch diese Konstruktion wird eine lebendige Einheit des Satzes hervorgebracht". Thus we find beside Hdt. 3, 26 हैs ...

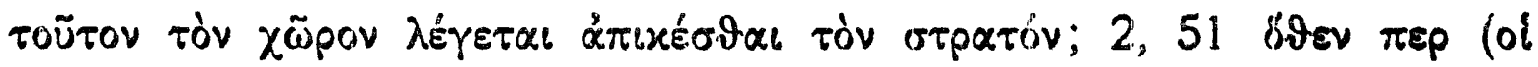

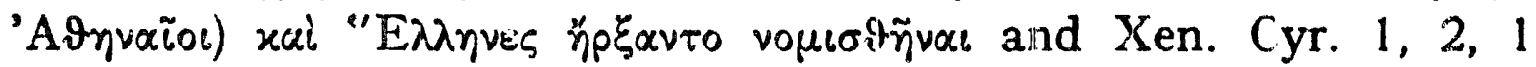

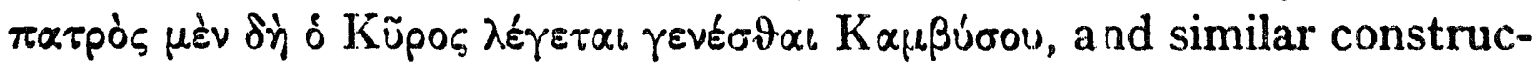

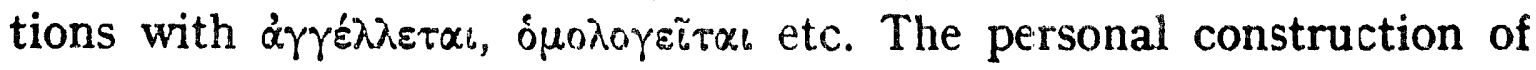
Soxeiv is much more frequent than the impersonal: Xen. An. 1, 4, 18

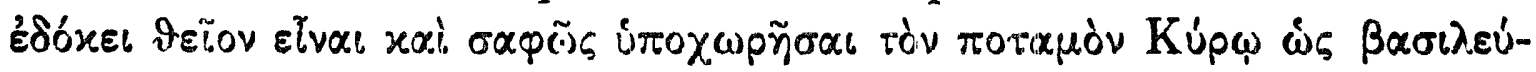

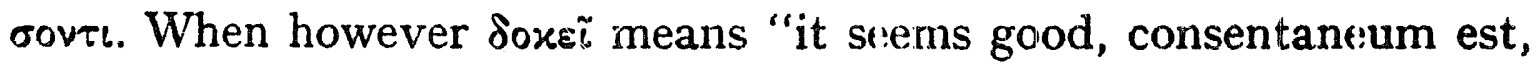
decernere" the impersonal construction is retained. Similarly, oup-

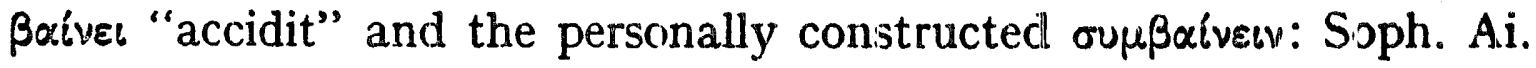

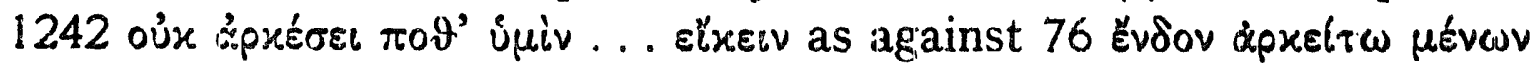
"let him be content to stay within".

The hypothesis may therefore be warranted that at least part of those Greek personal verbs whici express ideas which are in other ancient I.-E. languages denoted by impersonal constructions ("to be hungry, to regret, to rejoice, to iike" etc.) are as such younger and

203) This statement is not contradicted by the appearance of new impersonalia in more or less popular usage (e.g. non mihi vacat as against ou oxoג $\zeta_{\zeta}(a)$ "I have no time" ; habet +acc. in the sense of the German "es gibt" (cf. Fr. il $y$ a) in Vulgar Latin: see E. Löfstedt, Spätlateinische Studien, Skrifter K. Hım. Vet. Samf. Uppsala 12, p. 59).

202) R. Kühner-B. Gerth, Ausführliche Grammatik der Griechischen Sprache, II4, Leverkusen 1955, $\$ 477$, p. $33 \mathrm{ff}$. 
substitutes of ancient impersonal verbs. This hypothesis may be extended: the verb $\alpha^{2} \lambda \gamma^{\prime} \omega \omega$ "to feel bodily pain, suffer; to feel pain of

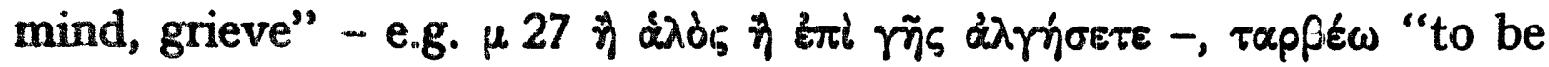

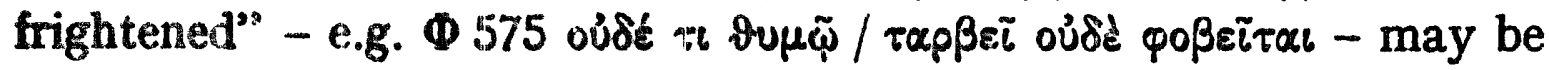
considered personal variants of the well-known expressions $\alpha \lambda \gamma$

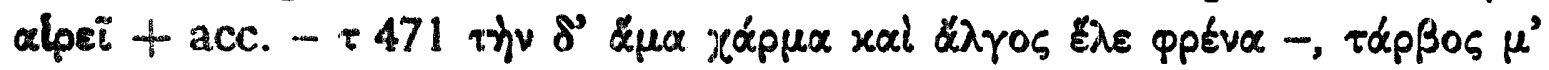
thes etc., in which the power affecting the victim is the explicit grammatical subject. It is of course impossible to decide how far analogical processes have accelerated, or extended influence upon, such a development. By this supposition the active forms of these verbs ( $\pi \varepsilon i v \tilde{\nu} v$, ¿̇yeiv etc.) would find a satisfactory explication.

Utrecht, van Hogendorpstraat 13

J. GONDA 